\title{
Egzoplaneta - alternatywa dla życia na Ziemi
}

\author{
Martyna Malinowska \\ Uniwersytet Gdański \\ Wydziat Oceanografii i Geografii, Instytut Oceanografii \\ E-mail:martynakali@gmail.com \\ tutor: dr hab. Anita Lewandowska, prof. UG \\ Uniwersytet Gdański \\ Wydział Oceanografii i Geografii, Instytut Oceanografii, Zakład Chemii Morza i Ochrony Środowiska Morskiego
}

Stowa kluczowe: egzoplaneta, astronomia, Ziemia, planeta pozastoneczna, druga Ziemia

Czy my, ludzie, jesteśmy sami we Wszechświecie? Czy istnieje gdzieś „druga Ziemia”? Te pytania ludzkość zadaje sobie od zarania dziejów. Dziś wiemy, że Wszechświat składa się z niezliczonej liczby gwiazd, które w większości posiadają własny układ planetarny, zbliżony do Układu Słonecz-nego. Są to tak zwane planety pozasłoneczne, inaczej zwane egzoplanetami (Amara i Quanz, 2012). Ich poszukiwania nie są już jedynie obiektem filmów science-fiction, czy teoretycznych dociekań naukowców. Dzięki postępowi technologicznemu, udało się udokumentować oraz potwierdzić istnienie egzoplanet. Jeszcze do niedawna nie było sposobów na wykrywanie tego typu ciał niebieskich. Znajdujące się w odległości wielu lat świetlnych od Ziemi, były one dla nas, ludzi, nieosiągalne do zbadania. Mimo to, pierwsze wzmianki o planetach pozasłonecznych pojawiły się już w XVI wieku. Włoski filozof Giordano Bruno wysnuł teorię, iż gwiazdy na niebie są odległymi ciałami niebieskimi, podobnie jak
Słońce otoczonymi przez swoje własne planety. Twierdził również, że Wszechświat jest nieskończony. Odkrycie pierwszej planety pozasłonecznej zabrało ludzkości kolejne 200 lat.

Radykalna zmiana w stanie wiedzy na temat egzoplanet nastąpiła w ostatnich trzech dziesięcioleciach. Była ona możliwa dzięki postępowi technologicznemu oraz rozwojowi instrumentów naziemnych i przyrządów obserwacyjnych umieszczonych w kosmosie. Do najważniejszych dokonań w dziedzinie astronomii egzoplanet przyczynił się w tym czasie między innymi polski naukowiec, Aleksander Wolszczan. W 1992 roku poinformował on o odkryciu dwóch skalistych planet wokół pulsara PSR B1257+12. Największy przełom nastąpił jednak w 1995 roku, gdy dwaj astronomowie z obserwatorium Genewskiego, Michel Mayor i Didier Queloz, ogłosili odkrycie gazowego olbrzyma wyglądem przypo-minjącego znanego nam Jowisza. Nazwano go Dimidium, 51 Pegasi b (Ryc. 1). Jest on oddalony od Ziemi o 50 lat świetlnych. Odkrycie to spowodowało szereg dalszych poszukiwań (Bridge, 2006). 


\section{Tutoring Gedanensis}



Ryc. 1. Dimidium, 51 Pegasi b [1]

W 2001 roku została odkryta pierwsza planeta pozałoneczna znajdująca się w strefie zamieszkiwalnej, tzw. ekosferze. Jest to obszar wokół gwiazdy, np. Słońca, w którym warunki fizyczne i chemiczne umożliwią rozkwit życia (Encyklopedia PWN, 2017). Planetę tę nazwano 70 Virginis b. Jest to gazowy olbrzym, ponad pięć razy masywniejszy od Jowisza. Pierwsze bezpośrednie zdjęcie tej egzoplanety (Ryc. 2) udało się uzyskać w 2004 roku za pomocą Bardzo Dużego Teleskopu (VLT ang. Very Large Telescope), należącego do Europejskiego Obserwatorium Południowego (ESO ang. European Southern Observatory) [2].

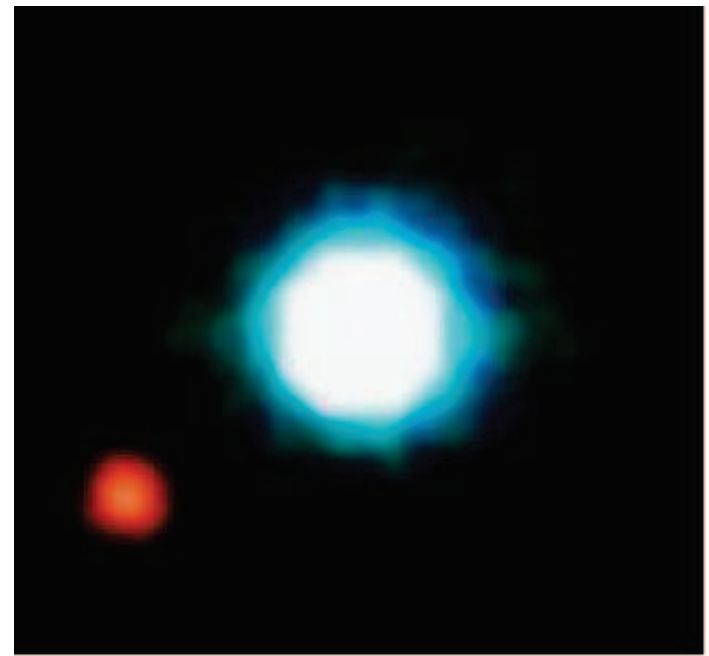

Ryc. 2. Autentyczne zdjęcie egzoplanety 2M1207 b [2]

Kolejne osiągniecie miało miejsce w maju 2007 roku, gdy za pomocą Kosmicznego Teleskopu Spitzera udało się opracować pierwszą prognozę pogody dla egzoplanety. Dwaj astronomowie, David Chaboronneau i Heather Knutson, uzyskali wówczas mapę rozkładu temperatury chmur na planecie HD189733 b. Dwa lata później, w marcu 2009 roku, odbył się start misji Kepler, prowadzonej przez NASA. Projekt, w którym wykorzystano metodę tranzytów, pozwolił na odkrycie największej (2300) do chwili obecnej ilości planet pozasłonecznych (Ryc. 3) [3]. Projekt zakończył się pod koniec 2018 roku.

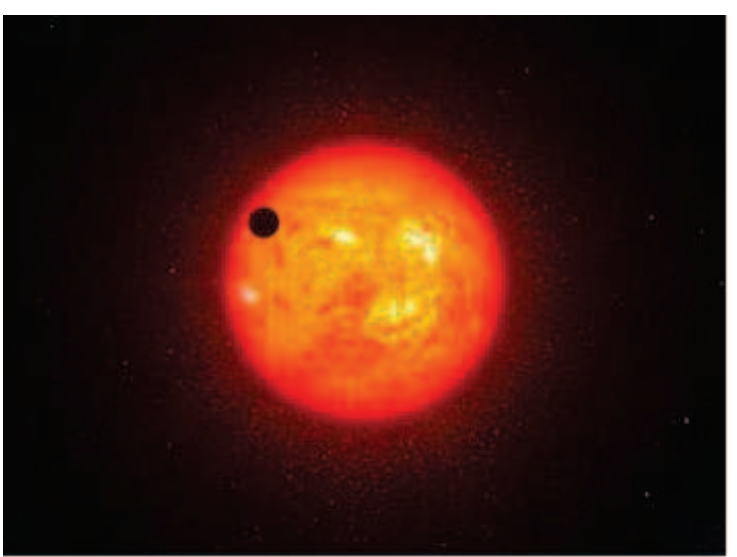

Ryc. 3. Planeta na tle gwiazdy [4]

Obecnie rozpoznanych jest 4410 planet obcych gwiazd [5]. Czy możliwym jest, że któraś z nich okaże się planetą, zdolną do zamieszkania? Dla wielu astronomów z całego świata znalezienie lustrzanego odbicia Ziemi w odległym kosmosie stanowi nadrzędny cel. Jaka powinna być planeta, na której mogłoby rozwinąć się życie? Czym powinna się ona charakteryzować?

Oczywiście najważniejszym kryterium jest jej położenie w ekosferze, która pozwoliłaby na rozkwit życia. Podstawowym warunkiem do podtrzymywania życia jest obecność wody. Jak dotąd, na liście egzoplanet położonych w strefie zamieszkiwalnej, znajdują się 24 takie planety. W 2019 roku, dzięki obserwacjom Kosmicznego Teleskopu Keplera, udało się ustalić, że w atmosferze planety K2-18b znajduje się para wodna (Ryc. 4). Nie można wykluczyć, 
że na tej egzoplanecie woda może pozostawać w stanie ciekłym [6].

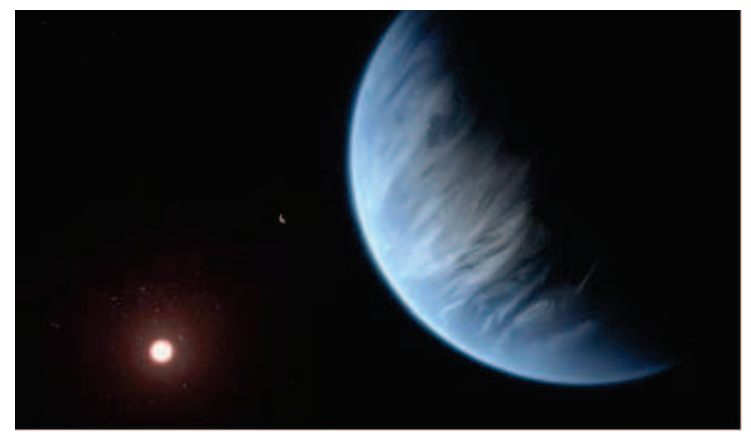

Ryc. 4. Artystyczna wizja wyglądu K2-18b [6]

Innym ważnym kryterium możliwości zasiedlenia bliźniaczej do Ziemi planety, jest posiadanie przez nią skalnej lub skalnolodowej powłoki jądra metalicznego. Taki typ planet charakteryzuje się dużą gęstością w porównaniu z gazowymi olbrzymami, stałą powierzchnią oraz niewielką masą [7]. Przykładem układu planetarnego, w którym rozmiary oraz masa planet sugerują, że są to ciała skaliste jest układ Trappist-1. Składa się on z siedmiu planet i jest położony około 40 lat świetlnych od Ziemi. Również w układzie Gliese 667 sugerowana jest obecność trzech planet skalistych w ekosferze (Ryc. 5) [8].

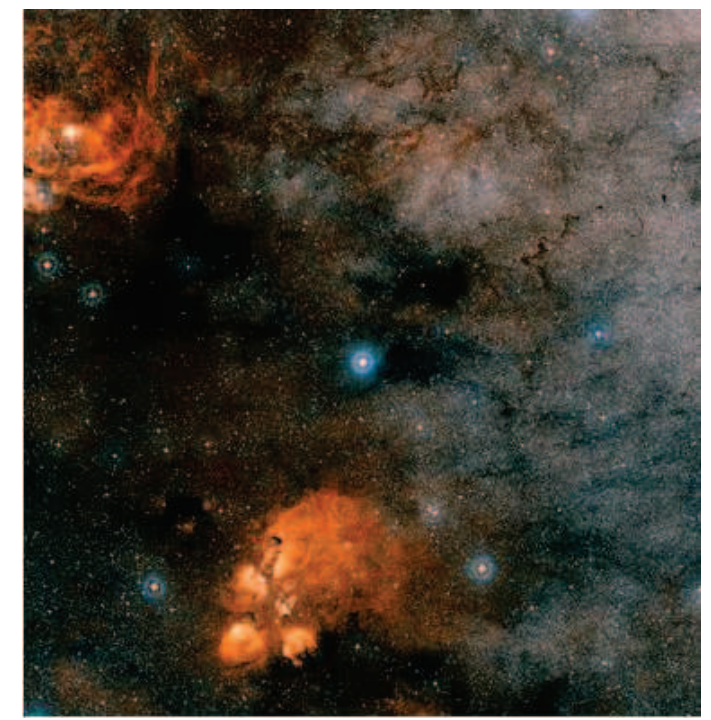

Ryc. 5. Widok nieba z Gwiazdą Gliese 667 w centrum. U dołu zdjęcia widoczna Mgławica Kocia Łapa [9]
Skalą, za pomocą której określa się wspólne cechy danej planety z naszą jest Indeks podobieństwa do Ziemi (ESI ang. Earth Similarity Index) (Tab. 1). Wartość zero oznacza brak, a jeden identyczność w podobieństwie. Wartości od 0,8 do 1 nadawane są planetom wysoce podobnym do Ziemi, które charakteryzują się stałą, skalną powierzchnią i stabilną atmosferą, zdolną do utrzymywania odpowiedniej temperatury [10]. Dla pięciu z nich ESI jest na imponującycm poziomie, powyżej 0,8.

Tab. 1. Planety o największym podobieństwie do Ziemi i ich odległość od Słońca wyrażona w latach

\begin{tabular}{lcc} 
& & świetlnych (ly) [11] \\
\hline Planeta & ESI & Odległość (ly) \\
\hline KOl-4878.01 & 0,98 & 1075 \\
\hline Proxima Centauri b & 0,87 & 4 \\
\hline Trappist-1e & 0,86 & 39 \\
\hline Gliese 667 Cc & 0,84 & 24 \\
\hline Kepler- 442b & 0,84 & 1115 \\
\hline Gliese 667 Cf & 0,77 & 24 \\
\hline Kepler-1229b & 0,73 & 769 \\
\hline Trappist-1f & 0,68 & 39 \\
\hline Kapteyn b & 0,67 & 13 \\
\hline Kepler-62f & 0,67 & 1200 \\
\hline Kepler-186f & 0,61 & 429 \\
\hline Gliese 667 Ce & 0,60 & 24 \\
\hline Trappist-1g & 0,58 & 39 \\
\hline
\end{tabular}

Znalezienie egzoplanety odpowiedniej do zamieszkania jest pierwszym krokiem procesu, który prawdopodobnie potrwa nawet kilka kolejnych pokoleń. Jakkolwiek poszukiwania wydają się być konieczne, zważywszy na złą kondycję Ziemi. Przeżywa ona obecnie wielki kryzys różnorodności biologicznej i z tego względu jest w niebezpieczeństwie. Przeprowadzone 
w ostanich latach przez NASA szacunki sugerują, że milionom zwierząt i roślin grozi wyginięcie z powodu działalności człowieka takiej jak wylesianie, polowania czy przełowienia [12]. Degradacja biosfery nasiliła się w XVIII wieku, wraz z zapoczątkowaniem rewolucji przemysłowej [13]. Na całym świecie wzrosło zużycie ropy, węgla igazu ziemnego. Obecnie, na skutek spalania paliw kopalnych każdego roku uwalnianych jest do atmosfery około 8,5 miliarda ton węgla w postaci $\mathrm{CO}_{2}$. Prowadzi to do wzrostu jego stężenia i wzmocnienia efektu cieplarnianego Ziemi. Od 1880 roku średnia temperatura powietrza wzrosła o około $0,9^{\circ} \mathrm{C}$. Przewiduje się, że jeśli spalanie paliw kopalnych pozostanie na obecnym poziomie, do roku 2100 średnia temperatura powietrza może wzrosnąć nawet o $4^{\circ} \mathrm{C}$ (IPCC 2014).

Kolejnym zagrożeniem dla Ziemi jest intensywnie postępujący w ciągu ostatnich 300 lat wzrost populacji ludzkiej. Obecnie na Ziemi żyje około siedem miliardów ludzi. Demografowie przewidują, że do 2050 roku populacja świata wzrośnie do dziewięciu miliardów, a pod koniec stulecia ustabilizuje się między dziewięcioma a 12 miliardami. Oznacza to wielokrotnie większą potrzebę pozyskiwania żywności, surowców mineralnych, czy energii.

Wzrost liczby ludności na Ziemi już obecnie jest jednym z głównych czynników prowadzących do globalnych zmian zachodzących w środowisku (Camill, 2010). Przedostają się do niego, uwalniane przez człowieka, toksyczne i niebezpieczne substancje, które wpływają negatywnie na organizmy żywe, w tym na zdrowie ludzi i jakość ich życia. Do takich zanieczyszczeń zaliczane są między nimi metale ciężkie, pestycydy wielopierścieniowe węglowodory aromatyczne (WWA), tworzywa sztuczne i wiele innych. Metale ciężkie, takie jak rtęć, ołów, kadm czy arsen, uwalniane są do wody, powietrza czy gleby podczas procesu wydobycia, ale także podczas spalania paliw kopalnych i pozyskiwania niektórych produktów, np.: farb i baterii. Wiele zanieczyszczeń emitowanych do powietrza, np. tlenki węgla. azotu i siarki oraz pył zawieszony bogaty WWWA czy metale ciężkie, pochodzi z zużycia węgla i ropy na cele grzewcze oraz transportowe. Poważne zagrożenie dla naszej planety stanowią ponadto odpady. Już obecnie na Oceanach Atlantyckim i Spokojnym znajdują się plamy śmieci, złożone głównie z plastiku, swoją wielkością odpowiadające trzykrotności powierzchni Polski (Camill, 2010).

Bezpośrednim zagrożeniem dla Ziemi są ponadto nieznane obiekty, pochodzące z przestrzeni kosmicznej. Naukowcy ustalili, że liczba ciał niebieskich które zagrażają Ziemi sięga obecnie około 20 tysięcy. Są to tak zwane Obiekty Bliskie Ziemi (NEO ang. Near Earth Objects), planetoidy, komety i meteoroidy [14]. Szacuje się, że na Ziemię codziennie spada od 100 do 1000 ton meteorytów. Czy zatem, jak twierdzą badacze: „bezkolizyjny czas Ziemi się skończył"? Większość z tych obiektów to zaledwie drobne okruchy. Te, które zagrażają ludzkości podlegają nieustannym obserwacjom. Są to obiekty o średnicy od 1,5 do 2 kilometrów. Wielkość tę uznaje się za wartość progową globalnej katastrofy, która mogłaby doprowadzić do zniszczeń, jakich gatunek ludzki jeszcze nie doświadczył [15]. Do tej pory, na szczęście, nie doszło jeszcze do upadku na Ziemię ciał niebieskich, które wywołałyby katastroficzne w skutkach konsekwencje dla ludzkości. Warto jednak wspomnieć o katastrofie tunguskiej, która wydarzyła się 30 czerwca 1908 roku. Miała ona miejsce w środkowej Syberii, nad rzeką Tunguzka. Asteroida o wielkości wieżowca, która rozpadła się na części, spowodowała olbrzymią eksplozję i powaliła drzewa w promieniu 40 km. Z kolei w 2004 roku, w mieście 


\section{Tutoring Gedanensis}

Leon w Hiszpanii, spadająca gwiazda świeciła tak jasno, że było ją widać w środku dnia. Nie doleciała ona jednak do Ziemi, gdyż spaliła się w atmosferze ziemskiej. Kolejne wydarzenie miało miejsce w lutym 2013 roku, gdy niewielka asteroida o średnicy 20 m spadła na rosyjski Czelabińsk. Spowodowało to silną falę uderzeniową i uszkodzenia 7500 budynków. W tej katastrofie zostało rannych ponad tysiąc pięćset osób [16].

Opisane powyżej zjawiska mają miejsce na całym świecie, a także w całym Układzie Słonecznym. Z tego względu stworzona została Database Earth Impact. Jest to baza potwierdzonych struktur udarowych lub kraterów na Ziemi. Ustalono, że jest ich łącznie 190 (Ryc. 6) [17]. Ostrzeżenia o zbliżającym się niebezpieczeństwie zderzenia Ziemi z ciałem obcym nie milkną. 23 grudnia 2004 roku, NASA poinfor-mowała świat, że 13 kwietnia 2029 roku, bardzo blisko Ziemi przeleci 40 metrowej średnicy planetoida Apophis. Prawdopodobieństwo jej zderzenia z naszą planetą ustalono na 1:37 [18]. Najnowsze doniesienia naukowców na ten temat sugerują, że szansa wejścia Apophis na kolizyjny tor $z$ naszą planetą będzie największa w 2068 roku.

Omówione powyżej zagrożenia mogą doprowadzić do zagłady życia na naszej planecie. W historii Ziemi pięciokrotnie odnotowano sytuację maso-wego wymierania i zaniku życia. Pierwsze znane masowe wymieranie nastąpiło z końcem ordowiku (485 do 444 milionów lat temu). W późnym dewonie, około 374 milionów lat temu, wyginęły organizmy morskie. Dokumentują to zlokalizowane na terenie dzisiejszych Niemiec skały z tamtego okresu.

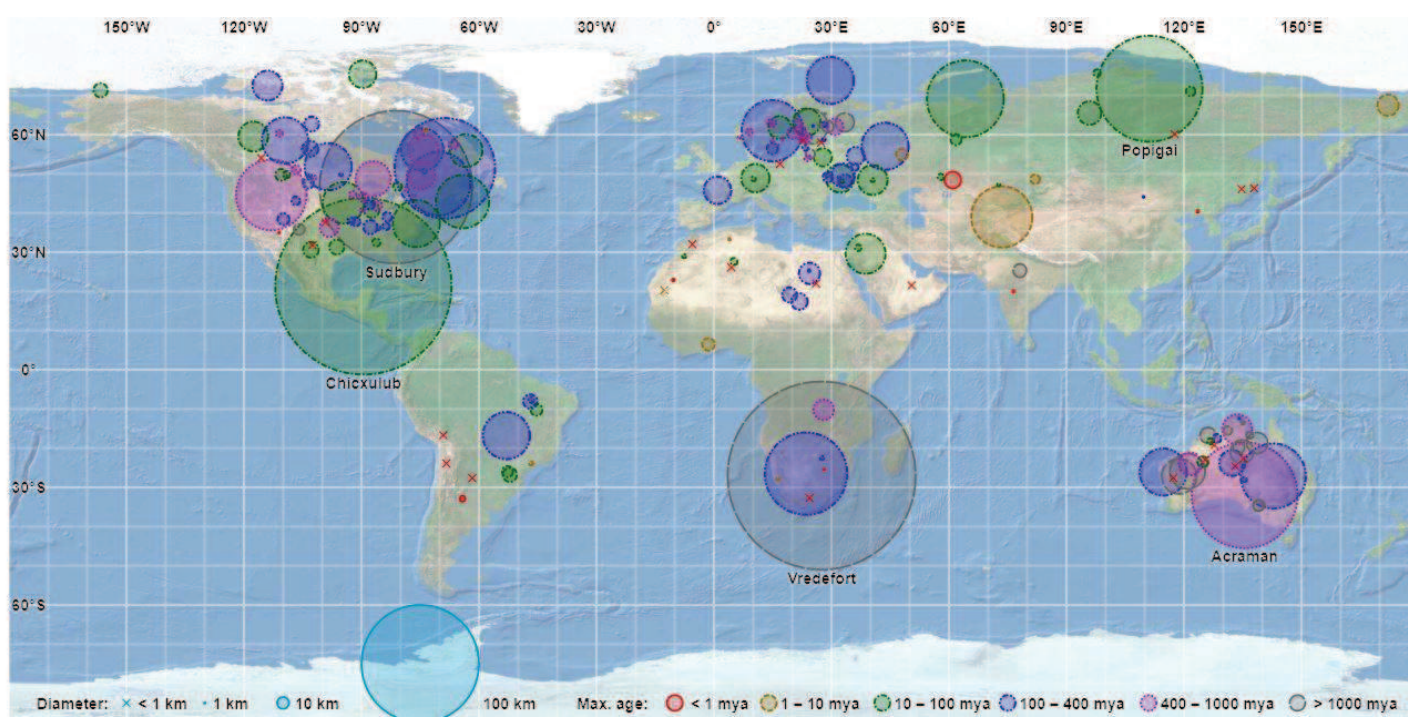

Ryc. 6. Rozmieszczenia 190 potwierdzonych struktur uderzenia meteorytów na Ziemię [19]

Ustalono, że ze spadkiem poziomu tlenu wymarło wiele stworzeń budujących rafy, w tym duża grupa gąbek morskich. Jednak największa zagłada organizmów żywych, jaka miała miejsce na Ziemi, przypadła na perm i trias. Wówczas w ciągu około 60000 lat wymarło 96\% wszystkich gatunków morskich i około trzech czwartych gatunków lądowych. Największą przyczyną wymierania były Syberyjskie Trapy, czyli ogromny kompleks wulkaniczny, z którego na teren dzisiejszej Syberii zostało wyrzucone ponad 720000 mil sześciennych lawy. Erupcja spowodowała uwolnienie do atmosfery co najmniej 14,5 biliona ton węgla. 
Kolejnego poważnego ciosu życie na Ziemi doznało 201 milionów lat temu. W masowym wymieraniu triasowo-jurajskim wyginęło wówczas do 80\% wszystkich gatunków lądowych i morskich. Wygaśnięcie kredy i paleogenu jest ostatnim masowym kataklizmem, który nastąpił na skutek uderzenia asteroidy. Doprowadził on do wyginięcia około $76 \%$ wszystkich gatunków organizmów żywych na naszej planecie, w tym wszystkich dinozaurów [20].

Nadrzędnym celem gatunku ludzkiego jest jego przetrwanie. W chwili obecnej wydaje się, że poza właściwym zarządzaniem Ziemią, jedyną na to szansę daje odkrycie planety do niej podobnej. Poszukiwanie pozasłonecznych planet nie należy jednak do łatwego zadania. Planety nie emitują światła, odbijają jedynie światło gwiazdy, wokół której krążą. Zatem są od niej dużo ciemniejsze i "giną" w jej jaskrawym blasku. Aby zrozumieć, z jakim problemem borykają się astronomowie poszukujący planety bliźniaczej do Ziemi wyobraźmy sobie, że z okolic koła podbiegunowego w Norwegii obserwujemy ćmę, która krąży wokół małej lampy w Egipcie (Neutrino, 2016). Aby obserwacja egzoplanety była możliwa konieczne jest wyeliminowanie blasku gwiazdy wokół której ona krąży. Jest to możliwe za pomocą przesłony, tak zwanego koronografu. Z rozwojem techniki powstało wiele metod, które umożliwiają obserwację egzoplanet. Jedną z najbardziej efektywnych jest metoda tranzytowa. Polega ona na obserwacji samej gwiazdy, wokół której krąży planeta (Ryc. 7). Obserwacje prowadzone są w odpowiednich interlineacjach czasu, w których planeta przysłania fragment znajdującej się za nią gwiazdy. W konsekwencji zmniejsza to jej blask, a cykliczne zmniejszanie jasności gwiazdy umożliwia wykrycie planety (Neutrino 2016). Metoda ta pozwala także na badanie składu chemicznego atmosfery danej planety. $W$ tym celu wykorzystywane jest zjawisko rozpraszania światła przez poszczególne składowe atmosfery.

Inną metodą pozwalającą na odnalezienie egzoplanet i obsewowanie ich faz jest fotometria światła emitowanego i odbitego. Z kolei do badań gwiazd znajdujących się w bardzo dużej odległości od Ziemi wykorzystywany jest efekt Dopplera. Dzięki mikrosoczewkowaniu grawitacyjnemu odkryto natomiast aż 106 planet. Metoda ta polega na obserwowaniu światła, które jest zaginane i skupiane przez grawitację, gdy planeta przechodzi między gwiazdą a Ziemią. Wszystkie opisane powyżej metody umożliwiają pozyskiwanie cennych informacji na temat panujących na powierzchni egzoplanet warunów, a także określić ich odległość od Ziemi.

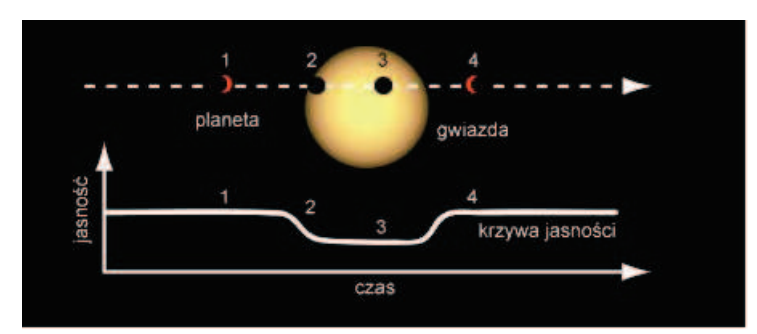

Ryc 7. Metoda tranzytowa. Obserwacja zmian jasności gwiazdy pozwala na detekcję planety przesuwającej się przed jej tarczą (Neutrino, 2016)

Teoretycznie możliwa jest podróż człowieka na najbliższą Ziemi egozplanetęProxima Centauri b, która oddalona jest o 4,22 lata świetlne (40 bilonów km). Jakkolwiek, przy obecnym stanie techniki zajęłoby to 6,5 tysiąca lat. Aby dotrzeć tam za życia jednego pokolenia statek kosmiczny musiałby poruszać się z prędkością co najmniej 5\% prędkości światła, czyli 15000 kilometrów na sekundę. Jak dotąd najszybszym obiektem zbudowanym przez człowieka jest Parker Solar Probe. Sonda ta jest w stanie podróżować z prędkością około 60 kilometrów na sekundę. Naukcy przepro- 
wadzili symulację i wyliczyli, że aby podróż na najbliższą planetę pozasłoneczną Proxima Centauri b, zakończyła się sukcesem, załoga musiałaby się składać z następujących po sobie 98 osób, dając gwarancję na przetrwanie w czasie podróży a w dalszym etapie założenie kolonii [21] [22]. Tak więc w chwili obecnej odległość jest tym czynnikiem, który najbardziej ogranicza możliwość zasiedlenia przez człowieka innej planety. Odkrycie planety przydatnej do zamieszkania wydaje się już bardzo prawdopodobne, zważywszy na szybki rozwój technologii. Być może nastąpi to już w październiku 2021 roku. Wówczas zaplanowano uruchomienie Kosmicznego Teleskopu Jamesa Webba. Jest to orbitujące w podczerwieni obserwatorium, które uzupełni i poszerzy odkrycia wykorzystywanego obecnie Kosmicznego Teleskopu Hubble'a. Nowy teleskop jest skonstruowany z 18 segmentów. Jego średnica wynosi 6,5 m, czyli 2,5 razy wiecej niż teleskopu Hubble'a. Oferuje on większy zasięg fal i znacznie poprawioną czułość. Pozwoli przyjrzeć się znacznie bliżej początkowi czasu i niedostrzeganemu do tej pory formowaniu się pierwszych galaktyk. Umozliwi ponadto zajrzenie do wnętrza obłoków pyłu, w których obecnie formują się gwiazdy i całe układy planetarne [23].

Czy istnieje życie poza Ziemią, w dalszym ciągu pozostaje jedną z najgłębszych tajemnic i pytań wszechczasów. Odpowiedź na to pytanie zmieni na zawsze nas ludzi i nasze postrzeganie Wszechświata. Wszechświata, w którego bezmiarze Ziemia jest zaledwie błękitną kropką (Ryc. 8).

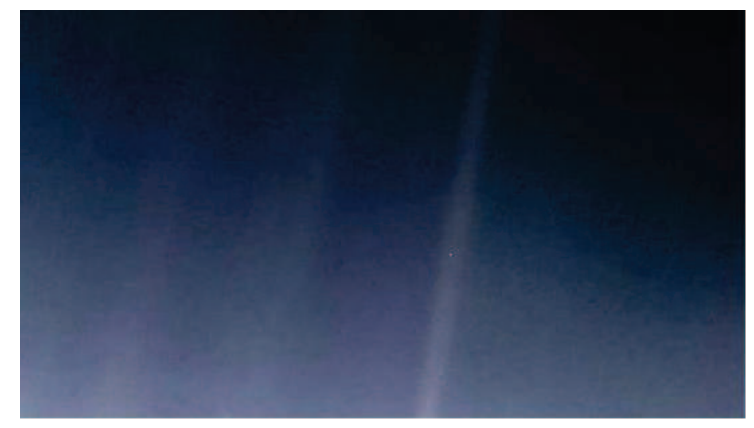

Ryc. 8. Zdjęcie Ziemi zrobione 14 lutego 1990 roku przez sondę Voyager 1 w odległości 6 miliardów kilometrów od Słońca. Obraz zainspirował tytuł książki naukowca Carla Sagana „Bladoniebieska kropka: wizja ludzkiej przyszłości w kosmosie”, w której napisał: „Spójrz jeszcze raz na tę kropkę.

To jest tutaj. To jest dom. To my" [24]

My ludzie, czujemy się bezbronni wobec możliwych zagrożeń ze strony kosmosu. Mam nadzieję, że dzięki zaawansowanej technologii, w tym nowemu Teleskopowi Jamesa Webba, poszerzą się możliwości badawcze i znikną przynajmniej niektóre tajemnice, jakie przed ludźmi skrywa Wszechświat. Ufam, że kiedyś poznamy szczegółowo nasze w nim miejsce i rolę. Nadchodzące dziesięciolecia, a może już tylko lata, przybliżą nas do odkrycia "drugiej Ziemi". Każdy z nas może przyczynić się do odkryć w dziedzinie astronomii. Zaproponowane przez NASA projekty zrzeszają tysiące ludzi, także amatorów. Korzystając z danych z misji NASA można odnaleźć planetę, czy inne ciało niebieskie: https://www.zooniverse.org/projects?discipli ne=astronomy \&page $=1 \&$ status $=$ live .

Wytarczy połączenie z internetem aby przyczynić się w badaniach i poszukiwaniu nowych, odległych światów. 


\section{Literatura:}

Amara A., Quanz S. P., 2012. PYNPOINT: an image processing package for finding exoplanets. Institute for Astronomy, ETH Zurich, Zurich 8093.

Bridge M., 2006. Egzoplanety- bliźniacze Ziemie, USA.

Camill, P., 2010. Global Change. Nature Education Knowledge 3(10): 49.

Encyklopedia popularna, 2017. Wydawnictwo Naukowe PWN.

IPCC Climate Change 2014: Impacts, Adaptation and Vulnerability. Contribution of Working Group II to the Fifthe Assessment Report of the Intergov. Panel on Climate Change. Cambridge University Press, 2014.

Neutrino, Pismo dla uczniów o fizyce i astronomii, Instytut fizyki Uniwersytet Jagielloński, 2016, nr 32,

http://www.neutrino.if.uj.edu.pl/documents/12578688/0875ed89-f269-4761aae7-a4ab7dd5ec0d

\section{Źródła internetowe:}

[1] https://upload.wikimedia.org/wikipedia/commons/f/f7/Artist_impression_ofthe_exoplanet51_Pegasi_b.jpg

[2] https://www.eso.org/public/poland/images/26a_big-vlt/

[3] https://www.nasa.gov/mission_pages/kepler/overview/index.html

[4] https://upload.wikimedia.org/wikipedia/commons/f/f7/Artist_impression_of_the_lexoplanet_51_Pegasi_b.jpg

[5] http://exoplanet.eu/catalog/

[6] https://www.bbc.com/news/science-environment-49648746

[7] https://pl.wikipedia.org/wiki/Planeta_skalista

[8] https://pl.wikipedia.org/wiki/Gliese_667

[9] https://upload.wikimedia.org/wikipedia/commons/d/de/Sky_around_Gliese_667C.jpg
[10] https://pl.linkfang.org/wiki/ESI

[11] http://phl.upr.edu/projects/habitable-exoplanets-catalog

[12] https://www.nationalgeographic.com/environment/global-warming/global-warming-effects/

[13] https://www.ekologia.pl/wiedza/slowniki/leksykon-ekologii-i-ochrony-srodowiska/biosfera

[14] http://astunit.com/astunit_tutorial.php?topic $=$ glossary $\# \mathrm{~N}$

[15] https://pl.wikipedia.org/wiki/Katastrofa_kosmiczna

[16] https://www.arcgis.com/apps/Cascade/index.html?ap-

pid $=077$ dabe158e84d5e8b4eb635ce8e4 251

[17] http://www.passc.net/EarthlmpactDatabase/New\%20website_05-2018/Index.html

[18] http://www.esa.int/Science_Exploration/Space_Science/Herschel_intercepts_asteroid_Apophis

[19] https://pl.qaz.wiki/wiki/List_of_impact_craters_on_Earth

[20] https://www.nationalgeographic.com/science/prehistoricworld/mass-extinction/

[21] http://www.planetariumec1.pl/aktualno\%C5\%9Bci/druga-ziemiatu\%C5\%BC-obok-nas

[22] https://innpoland.pl/156857,naukowcy-rozwazaja-problemy-zwiazane-z-podrozapoza-uklad-sloneczny

[23] https://www.jwst.nasa.gov/index.html

[24] https://www.national-geographic.pl/artykul/tak-samotna-jest-ziemia-w-kosmosie-nasa-odswiezyla-slynne-zdjecie

Notka o autorce: Studentka pierwszego roku studiów magisterskich na kierunku Oceanografia, specjalność chemia morza i atmosfery. 